\title{
Heritability of Length of Reproductive Period and Rate of Seed Mass Accumulation in Common Beans
}

\author{
James S. Beaver \\ Department of Agronomy and Soils, University of Puerto Rico, Mayaguez, PR 00681 \\ Juan Carlos Rosas \\ Department of Agronomy, Escuela Agrícola Panamericana, P.O. Box 93, Tegucigalpa, Honduras
}

AdDitional INDEX words. Phaseolus vulgaris, crop physiology, yield

\begin{abstract}
Anstract. Heritability of length of the reproductive period and rate of seed mass accumulation in beans (Phaseolus vulgaris $L_{\text {.) }}$ was estimated using 170 randomly derived $F_{6}$ and $F_{7}$ lines from three populations evaluated in the field in Puerto Rico and Honduras during two growing seasons. Narrow-sense heritability for length of reproductive period ranged from moderate $(\mathbf{0 . 4 3})$ to high $(\mathbf{0 . 8 3})$, and transgressive segregation for shorter and longer reproductive period was observed for the three populations. Heritability of rate of seed mass accumulation was low (0.24) to intermediate (0.49). Lines with high yield potential, which matured 4 to 7 days earlier than the later parents L227-1 and 'Catrachita', were selected. Most of the superior lines combined earlier maturity with high yield potential by having greater rates of seed mass accumulation than the early parents 'Cuarentena' and 'Cuarenteño'. Low to intermediate heritabilities for rate of seed mass accumulation suggest that selection for this trait would be more effective by evaluating advanced generation lines in replicated trials. Several lines yielded significantly more than L227-1 or 'Catrachita' by combining long reproductive period with fast rate of seed mass accumulation.
\end{abstract}

Landrace cultivars of common beans (Phaseolus vulgaris) in Honduras and Puerto Rico tend to mature earlier than higheryielding breeding lines. Earliness enables cultivars to avoid drought at the end of the growing scason (Janssen, 1989). In Pucrto Rico, earlier maturity permits growers of green-shell beans to obtain higher prices and avoid diseases that are more severe toward the end of the growing season (Badillo-Feliciano et al., 1985). Early maturity also is associated with lower yield potential. White and Singh (1991) reported that in Palmira, Colombia, each day of increase in earliness resulted in a $74 \mathrm{~kg} \cdot \mathrm{ha}^{-1}$ decrease in seed yield.

The yield potential of earlier-maturing beans might be improved by selecting lines that combine early flowering with earlier maturity. Selection for this combination of traits would not shorten the reproductive period, which is the interval from the initiation of anthesis to physiological maturity. Izquierdo and Hosfield (1983) evaluated nine common bean lines that varied in plant architecture and reported that an indeterminate bean archetype achieved higher yield than determinate beans through a longer filling duration that led to a larger sink size. Beaver and Kelly (1994) found that gain in yield from recurrent selection of larger-seeded bean lines was due to a longer reproductive period and later maturity. Beaver and Rosas (1992) reported that bean lines varying by as much as $10 \mathrm{~d}$ in length of reproductive period could be selected from crosses between early-and late-maturity parents. Smith and Nelson (1986) reported a positive correlation between the length of the reproductive period and seed yield of soybean. However, heritabilities for reproductive growth period in soybeans were not greater than those for seed yield. Pfeiffer and Egli (1988) found that heritabilities based on regression of $\mathrm{F}_{2: 4}$ progeny on $\mathrm{F}_{2: 3}$ parents for duration of the reproductive period ( $\mathrm{R} 1$ to $\mathrm{R} 8$ ) in soybeans to range from 0.37 to 0.82 .

Another approach to increase seed yield in beans would be to select lines having a greater rate of seed mass accumulation.

Received for publication 12 May 1996. Accepted for publication 7 Jan. 1998. This study was supported by Title XII Bean/Cowpea CRSP (USAID No. DAN-1310-G$6008-00$ ). The cost of publishing this paper was defrayed in part by the payment of page charges. Under postal regulations, this paper therefore must be hereby marked advertisement solely to indicate this fact.
Adams (1967) suggested that higher yields could be achieved if photosynthate were directed into the seeds more efficiently. Wallace et al. (1993) noted that, for common beans and many other crops, therc is an association of carly maturity with high harvest index. They also suggested that the rate of yield accumulation controls days to maturity and, thereby, the adaptation of a cultivar to the duration of the growing season.

The objectives of this research were to 1) describe the length of reproductive period and the rate of seed mass accumulation of common bean lines selected to combine earlier maturity with high yield potential and 2) estimate heritability of length of the reproductive period and rate of seed mass accumulation in three common bean populations.

\section{Materials and Methods}

Randomly derived $\mathrm{F}_{6}$ and $\mathrm{F}_{7}$ lines from three common bean populations were evaluated in field trials in Puerto Rico and Honduras. Two populations were developed from reciprocal crosses between the early-maturing, white-seeded landrace cultivar 'Cuarentena' and the later maturing white-seeded breeding line L227-1. The later-maturing small red cultivar 'Catrachita' was crossed with the early-maturing, small red landrace cultivar 'Cuarenteño' to develop the third population. All of the parents have an indeterminate Type II growth habit (CIAT, 1987). The $F_{1}$ and $F_{2}$ generations were planted at the Isabela Substation in Puerto Rico in October 1987 and January 1988, respectively. The $F_{2: 3}$ progenies from randomly selected $\mathrm{F}_{2}$ plants were planted at the Isabela Substation in May 1988. The $F_{3: 4}$ and $F_{4: 5}$ generations were planted at the Isabela Substation in October 1989 and January 1990 , respectively. Individual $F_{5}$ plants were harvested to obtain the $F_{6}$ seed used for the first year of evaluation.

The lines and parents were evaluated in field trials using a randomized complete-block design with three replications. The 'Cuarenteño' $x$ 'Catrachita' population contained 54 lines. The L227-1 X 'Cuarentena' and the 'Cuarentena' X L227-1 populations each contained 58 lines. Plots consisted of single $1-\mathrm{m}$ rows with 0.6-m centers and planted with 12 seeds. The Puerto Rico trials were planted on a Coto Clay (Clayey, kaolinitic, isohyperthermic 
Table 1. Narrow sense heritabilities $\left(\mathrm{h}^{2}\right)$, means, and ranges of reproductive periods of parents $(\mathrm{P} 1$ and $\mathrm{P} 2)$ and randomly derived $\mathrm{F}_{6}$ and $\mathrm{F}_{7}$ lines of white and small red bean breeding populations evaluated in Puerto Rico (PR) and Honduras (HO).

\begin{tabular}{|c|c|c|c|c|c|c|c|}
\hline \multirow[b]{2}{*}{$\begin{array}{l}\text { Cross } \\
(\mathrm{P} 1 \times \mathrm{P} 2)\end{array}$} & \multirow[b]{2}{*}{ Location } & \multirow[b]{2}{*}{ Year } & \multirow[b]{2}{*}{$h^{2} \pm S E$} & \multicolumn{4}{|c|}{ Reproductive period (d) } \\
\hline & & & & $\begin{array}{c}\text { Population } \\
\text { mean }\end{array}$ & Range & $\begin{array}{c}\text { Mean } \\
\text { P1 }\end{array}$ & $\begin{array}{c}\text { Mean } \\
\text { P2 }\end{array}$ \\
\hline \multirow[t]{2}{*}{ Cuarentena x L227-1 } & $\mathrm{PR}$ & 1990 & $0.46 \pm 0.21$ & 38.0 & $32.0-44.3$ & 37.7 & 37.0 \\
\hline & & 1991 & $0.47 \pm 0.21$ & 40.0 & $34.3-47.7$ & 43.3 & 35.0 \\
\hline \multirow[t]{2}{*}{ L227-1 x Cuarentena } & PR & 1990 & $0.43 \pm 0.21$ & 39.5 & $33.7-50.3$ & 39.7 & 39.3 \\
\hline & & 1991 & $0.75 \pm 0.23$ & 38.8 & $33.0-49.6$ & 34.0 & 44.1 \\
\hline \multirow[t]{2}{*}{ Cuarenteño $\times$ Catrachita } & PR & 1990 & $0.46 \pm 0.22$ & 40.8 & $34.0-47.3$ & 40.3 & 40.0 \\
\hline & & 1991 & $0.58 \pm 0.23$ & 41.2 & $34.3-46.7$ & 37.7 & 41.7 \\
\hline \multirow[t]{2}{*}{ Cuarenteño $x$ Catrachita } & $\mathrm{HO}$ & 1990 & $0.83 \pm 0.24$ & 36.8 & $30.7-40.0$ & 35.7 & 36.7 \\
\hline & & 1992 & $0.55 \pm 0.23$ & 34.5 & $30.7-40.0$ & 34.3 & 34.7 \\
\hline
\end{tabular}

Tropeptic Haplorthox) at the Isabela Substation on 21 Sept. 1990 and 17 Oct. 1991. The trials in Honduras were planted on a sandy loam, isohyperthermic Mollic Ustifluvent at the Escuela Agrícola Panamericana on 6 June 1990 and 27 Sept. 1992 . Nitrogen was applied at a rate of $50 \mathrm{~kg} \cdot \mathrm{ha}^{-1}$ and irrigation was used when needed to prevent drought stress. Weeds, disease, and insects were controlled during the growing season.

Date of initiation of anthesis was recorded when one-half of the plants in a plot had at least one open flower. Date of physiological maturity was recorded when one-half of the plants in the plot had only one green pod remaining (Cerna and Beaver, 1989). Length of the reproductive period was calculated as the difference between physiological maturity and date of initiation of anthesis. At harvest, the number of plants per plot was counted and the seed mass per plot was recorded. Seed mass per plant was calculated. The rate of seed mass accumulation during the reproductive period was calculated. The data from Puerto Rico and Honduras were analyzed in separate analyses of variance that were combined across years. Line means were compared by using protected least significant differences $(P \leq 0.05)$. Narrow-sense heritabilities were estimated on a progeny mean basis as follows: narrow-sense heritability $=\mathrm{h}^{2}{ }_{\mathrm{NS}}=\sigma_{\mathrm{A}}^{2} / \sigma_{\mathrm{P}}^{2} ;$ Additive genetic variance for $\mathrm{F}_{6}$ lines $=\sigma^{2}{ }_{A}=\sigma_{\text {(among }}^{2} 6$ lines) $\times(15 / 8)$; additive genetic variance for $F_{7}$ lines $=\sigma_{\mathrm{A}}^{2}=\sigma^{2}$ (among F l lines) $\times(31 / 16)$; phenotypic variance $=\sigma_{\mathrm{p}}^{2}=\left[\sigma_{\mathrm{A}}^{2}+\right.$ $\left.\left(\sigma_{\mathrm{E}}^{2} / \mathrm{r}\right)\right]$, where $\sigma_{\mathrm{E}}^{2}=$ error mean square and $\mathrm{r}=$ number of replications.

\section{Results and Discussion}

There was significant line $\times$ environment interaction for length of reproductive period in all of the combined analyses of variance. The range of the length of reproductive period was similar between years for the 'Cuarentena' $x$ L227-1 and L227-1 x 'Cuarentena' populations (Table 1), but the mean for the 'Cuarenteño' $x$ 'Catrachita' population was 3 to $4 \mathrm{~d}$ greater in Puerto Rico than in Honduras. Transgressive segregation for shorter and longer reproductive period was observed for all three populations (Table 1). Lines were selected within the small red and white-seeded populations that differed by $>25 \%$ in length of reproductive period. Narrow-sense heritability estimates for the length of the reproductive period ranged from moderate $(0.43)$ to large $(0.83)$.

Only the combined analysis of variance for the 'Cuarenteño' $x$ 'Catrachita' population evaluated in Honduras produced significant line $\times$ environment interaction for rate of seed mass accumulation. Transgressive segregation for rate of seed mass accumulation was observed within the three populations (Table 2). In every trial, there was at least a 2-fold difference among lines in rate of seed mass accumulation. The greater yield potential of $L 227-1$ and 'Catrachita' was due in part to greater rate of seed mass accumulation. L227-1 had a greater rate of seed fill than 'Cuarentena', and 'Catrachita' had a greater rate of seed mass accumulation than 'Cuarenteño' in three of the four environments in which they were tested. In all environments, narrow-sense heritabilities for rate of seed mass accumulation were low $(0.23)$ to intermediate $(0.49)$ for the three populations (Table 2).

The coefficients of variability for flowering date and physiological maturity were $\leq 8 \%$ in all of the environments (Tables $3-$ 6 ), which provided precise estimates for reproductive period. The coefficients of variability of seed mass per plant, on the other hand, ranged from $27.4 \%$ to $34.8 \%$ and, consequently, heritability estimates for rate of seed mass accumulation during the reproductive period were lower than the estimates for reproductive period. Although single-row 1-m plots and three replications provided adequate precision to detect differences among lines in seed mass

Table 2. Narrow sense heritabilities $\left(\mathrm{h}^{2}\right)$, means, and ranges of seed mass accumulation of parents ( $\mathrm{P} 1$ and $\left.\mathrm{P} 2\right)$ and randomly derived $\mathrm{F}_{6}$ and $\mathrm{F}_{7}$ lines of white and small red bean breeding populations evaluated in Puerto Rico (PR) and Honduras (HO).

\begin{tabular}{|c|c|c|c|c|c|c|c|}
\hline \multirow[b]{2}{*}{$\begin{array}{l}\text { Cross } \\
(\mathrm{P} 1 \times \mathrm{P} 2)\end{array}$} & \multirow[b]{2}{*}{ Location } & \multirow[b]{2}{*}{ Year } & \multirow[b]{2}{*}{$h^{2} \pm S E$} & \multicolumn{4}{|c|}{$($ Seed mass/plant)/d (g) } \\
\hline & & & & $\begin{array}{c}\text { Population } \\
\text { mean }\end{array}$ & Range & $\begin{array}{c}\text { Mean } \\
\text { P1 }\end{array}$ & $\begin{array}{c}\text { Mean } \\
\text { P2 }\end{array}$ \\
\hline \multirow[t]{2}{*}{ Cuarentena x L227-1 } & PR & 1990 & NS & 0.31 & $0.20-0.70$ & 0.18 & 0.33 \\
\hline & & 1991 & $0.35 \pm 0.21$ & 0.47 & $0.22-0.85$ & 0.40 & 0.60 \\
\hline \multirow[t]{2}{*}{ L227-1 x Cuarentena } & PR & 1990 & $0.49 \pm 0.21$ & 0.29 & $0.08-0.57$ & 0.25 & 0.24 \\
\hline & & 1991 & $0.34 \pm 0.20$ & 0.44 & $0.14-0.71$ & 0.51 & 0.33 \\
\hline \multirow[t]{2}{*}{ Cuarenteño $\times$ Catrachita } & PR & 1990 & $0.34 \pm 0.22$ & 0.41 & $0.27-0.63$ & 0.35 & 0.50 \\
\hline & & 1991 & $0.45 \pm 0.22$ & 0.35 & $0.16-0.64$ & 0.25 & 0.35 \\
\hline \multirow[t]{2}{*}{ Cuarenteño $\times$ Catrachita } & $\mathrm{HO}$ & 1990 & $0.31 \pm 0.21$ & 0.40 & $0.22-0.66$ & 0.50 & 0.31 \\
\hline & & 1992 & $0.23 \pm 0.21$ & 0.34 & $0.24-0.46$ & 0.33 & 0.41 \\
\hline
\end{tabular}


Table 3. Mean days to first flower (F), days to maturity (M), length of the reproductive period (R), seed mass/plant/day [(S/P)/R], seed mass/plant (S/ $\mathrm{P}$ ), and seed mass/plot ( $\mathrm{S}$ ) of the parents and seven $\mathrm{F}_{6}$ and $\mathrm{F}_{7}$ lines selected from the population L227-1 $\times$ Cuarentena evaluated in Isabela, Puerto Rico, in 1990 and 1991.

\begin{tabular}{|c|c|c|c|c|c|c|}
\hline \multirow{2}{*}{$\begin{array}{l}\text { Line or } \\
\text { parent }\end{array}$} & $\mathrm{F}$ & $\mathrm{M}$ & $\mathrm{R}$ & $(\mathrm{S} / \mathrm{P}) / \mathrm{R}$ & $\mathrm{S} / \mathrm{P}$ & $\mathrm{S}$ \\
\hline & \multicolumn{3}{|c|}{ (d) } & \multicolumn{3}{|c|}{ (g) } \\
\hline $9151-19$ & 39.0 & 76.7 & 37.7 & 0.43 & 16.0 & 105.3 \\
\hline $9151-24$ & 34.2 & 76.8 & 42.7 & 0.50 & 21.5 & 84.3 \\
\hline $9151-16$ & 39.3 & 76.8 & 37.5 & 0.58 & 21.5 & 100.8 \\
\hline $9151-13$ & 37.5 & 73.7 & 36.2 & 0.45 & 16.2 & 105.0 \\
\hline $9151-26$ & 33.0 & 75.2 & 42.2 & 0.40 & 16.8 & 115.7 \\
\hline $9151-18$ & 39.3 & 78.2 & 38.8 & 0.44 & 17.1 & 123.7 \\
\hline $9151-21$ & 38.7 & 79.2 & 40.5 & 0.64 & 25.9 & 131.5 \\
\hline L227-1 & 40.8 & 82.5 & 41.7 & 0.38 & 16.4 & 91.2 \\
\hline Cuarentena & 31.3 & 68.2 & 36.8 & 0.29 & 10.4 & 69.2 \\
\hline $\operatorname{LSD}(0.05)$ & 2.3 & 3.0 & 2.5 & 0.15 & 5.8 & 25.1 \\
\hline $\mathrm{CV}(\%)$ & 5.1 & 3.1 & 7.3 & 32.5 & 32.6 & 32.6 \\
\hline
\end{tabular}

Table 4. Mean days to first flower (F), days to maturity (M), length of the reproductive period (R), seed mass/plant/day [(S/P)/R], seed mass/plant (S/ $\mathrm{P}$ ), and seed mass/plot (S) of the parents and four $\mathrm{F}_{6}$ and $\mathrm{F}_{7}$ lines selected from the population Cuarentena $\times$ L227-1 evaluated in Isabela, Puerto Rico, in 1990 and 1991.

\begin{tabular}{|c|c|c|c|c|c|c|}
\hline \multirow{2}{*}{$\begin{array}{l}\text { Line or } \\
\text { parent }\end{array}$} & $\mathrm{F}$ & $\mathbf{M}$ & $\mathbf{R}$ & $(\mathrm{S} / \mathrm{P}) / \mathrm{R}$ & $\mathrm{S} / \mathrm{P}$ & $\mathrm{S}$ \\
\hline & \multicolumn{3}{|c|}{ (d) } & \multicolumn{3}{|c|}{ (g) } \\
\hline $9150-08$ & 37.3 & 76.7 & 39.3 & 0.57 & 21.5 & 113.8 \\
\hline $9150-20$ & 38.6 & 76.4 & 37.8 & 0.55 & 22.1 & 81.2 \\
\hline $9150-33$ & 35.0 & 74.8 & 39.8 & 0.56 & 22.5 & 91.0 \\
\hline $9150-43$ & 36.5 & 77.8 & 41.3 & 0.52 & 21.4 & 104.8 \\
\hline L227-1 & 41.3 & 81.8 & 40.5 & 0.46 & 19.0 & 101.2 \\
\hline Cuarentena & 31.5 & 67.5 & 36.0 & 0.29 & 10.5 & 52.5 \\
\hline $\operatorname{LSD}(0.05)$ & 2.5 & 3.3 & 4.0 & 0.19 & 7.6 & 36.7 \\
\hline $\mathrm{CV}(\%)$ & 5.5 & 3.4 & 8.0 & 39.1 & 39.3 & 34.8 \\
\hline
\end{tabular}

Table 5. Mean days to first flower (F), days to maturity (M), length of the reproductive period (R), seed mass/plant/day [(S/P)/R], seed mass/plant (S/ $\mathrm{P}$ ), and seed mass/plot (S) of the parents and five $\mathrm{F}_{6}$ and $\mathrm{F}_{7}$ lines selected from the population Cuarenteño $x$ Catrachita evaluated in Isabela, Puerto Rico, in 1990 and 1991.

\begin{tabular}{|c|c|c|c|c|c|c|}
\hline \multirow{2}{*}{$\begin{array}{l}\text { Line or } \\
\text { parent }\end{array}$} & $\mathrm{F}$ & $\mathbf{M}$ & $\mathrm{R}$ & $(\mathrm{S} / \mathrm{P}) / \mathrm{R}$ & $\mathrm{S} / \mathrm{P}$ & $S$ \\
\hline & \multicolumn{3}{|c|}{ (d) } & \multicolumn{3}{|c|}{ (g) } \\
\hline $9153-36$ & 39.0 & 74.8 & 35.8 & 0.52 & 18.8 & 121.0 \\
\hline $9153-14$ & 35.5 & 73.7 & 38.2 & 0.49 & 18.6 & 141.0 \\
\hline $9153-02$ & 35.0 & 72.7 & 37.7 & 0.43 & 16.6 & 121.2 \\
\hline $9153-15$ & 34.3 & 71.7 & 37.3 & 0.48 & 17.9 & 144.2 \\
\hline $9153-18$ & 36.0 & 78.3 & 42.3 & 0.60 & 25.2 & 190.2 \\
\hline Cuarenteño & 31.5 & 70.5 & 39.0 & 0.30 & 11.8 & 97.2 \\
\hline Catrachita & 37.7 & 78.5 & 40.8 & 0.42 & 17.4 & 129.8 \\
\hline $\operatorname{LSD}(0.05)$ & 2.6 & 2.5 & 3.3 & 0.12 & 5.0 & 34.4 \\
\hline $\mathrm{cV}(\%)$ & 6.2 & 2.8 & 6.9 & 27.1 & 28.8 & 27.5 \\
\hline
\end{tabular}

per plant, larger plots and more replications may be needed for selection based on seed yield estimates.

Six lines in the L227-1 $\times$ 'Cuarentena' population equalled or surpassed L227-1 in yield when averaged over the 1991 and 1992 growing seasons in Puerto Rico but reached maturity in significantly fewer days than L227-1 (Table 3). Although the six lines were intermediate between 'Cuarentena' and L227-1 in flowering date, they matured from 4 to 9 d earlier than L227-1. Two of the six lines had a longer reproductive period than 'Cuarentena' and four lines had a greater rate of seed mass accumulation during the reproductive period than 'Cuarentena'. One breeding line, 915121 , was similar to L227-1 in maturity but yielded significantly more by combining a long reproductive period with a rate of seed mass accumulation during the reproductive period significantly greater than that of L227-1.

Four lines in the 'Cuarentena' $x$ L227-1 population yielded as well as L227-1, but matured in 4 to 7 fewer days than L227-1 (Table 4), even though their flowering dates were intermediate between L227-1 and 'Cuarentena'. Only one of the four had a longer reproductive period than 'Cuarentena', whereas all had a greater rate of seed fill than 'Cuarentena'.

In Puerto Rico, the small red cultivar 'Catrachita' reached maturity 2 to 3 d earlier than L227-1 (Tables 3-5). Four lines in the 'Cuarenteño' $x$ 'Catrachita' population evaluated in Puerto Rico 
Table 6. Mean days to first flower (F), days to maturity $(\mathrm{M})$, length of the reproductive period $(\mathrm{R})$, seed mass/plant/day [(S/P)/R], and seed mass/plant (S) of the parents and six $\mathrm{F}_{6}$ and $\mathrm{F}_{7}$ lines selected from the population Cuarenteño $\times$ Catrachita evaluated in Zamorano, Honduras, in 1990 and 1992.

\begin{tabular}{|c|c|c|c|c|c|}
\hline \multirow{2}{*}{$\begin{array}{l}\text { Line or } \\
\text { parent }\end{array}$} & $\mathrm{F}$ & $\mathbf{M}$ & $\mathrm{R}$ & $(\mathrm{S} / \mathrm{P}) / \mathrm{R}$ & $S$ \\
\hline & \multicolumn{3}{|c|}{ (d) } & \multicolumn{2}{|c|}{ (g) } \\
\hline $9153-43$ & 37.3 & 71.7 & 34.3 & 0.49 & 16.8 \\
\hline $9153-51$ & 36.5 & 71.2 & 34.7 & 0.46 & 15.8 \\
\hline $9153-08$ & 37.8 & 71.8 & 34.0 & 0.45 & 15.4 \\
\hline $9153-27$ & 35.0 & 69.0 & 34.0 & 0.44 & 15.1 \\
\hline $9153-20$ & 38.3 & 76.3 & 37.3 & 0.50 & 19.7 \\
\hline $9153-34$ & 39.3 & 75.5 & 36.2 & 0.50 & 18.0 \\
\hline Cuarenteño & 33.0 & 67.0 & 33.7 & 0.42 & 14.2 \\
\hline Catrachita & 38.1 & 73.7 & 35.5 & 0.36 & 12.6 \\
\hline $\operatorname{LSD}(0.05)$ & 1.3 & 1.6 & 1.7 & 0.12 & 4.1 \\
\hline $\mathrm{CV}(\%)$ & 3.0 & 1.9 & 4.3 & 26.9 & 27.4 \\
\hline
\end{tabular}

yielded as well as 'Catrachita' but matured in fewer days (Table 5). The reproductive periods of three of the four lines were similar to 'Cuarenteño' and 'Catrachita', whereas one line had a shorter reproductive period than either parent. All four lines had seed filling rates significantly greater than that of 'Cuarenteño'. One line produced significantly greater yield than 'Catrachita' and 'Cuarenteño' by combining a long reproductive period with a seed mass accumulation rate greater than either parent. The flowering dates of the lines were similar or a few days earlier than 'Catrachita', the later maturing parent, and matured from 4 to 7 d earlier than 'Catrachita'.

'Catrachita' in Honduras matured 4.8 d earlier than 'Catrachita' in Puerto Rico, whereas 'Cuarenteño' flowered 3.5 d earlier in Honduras than in Puerto Rico (Tables 4-6). Four lines in the 'Cuarenteño' $x$ 'Catrachita' population yielded as well as 'Catrachita' in Honduras but matured in fewer days (Table 6). The reproductive periods of these lines were similar to the parents, whereas only one line had a seed mass accumulation rate significantly greater than that of 'Catrachita'. In Honduras, the rate of seed fill of 'Cuarenteño' was as great as that of 'Catrachita'. Two lines that produced greater seed mass per plant were identified by combining reproductive periods that were longer than that of Cuarenteño with rates of seed mass accumulation that were greater than that of 'Catrachita'. The flowering dates of the four lines were 1 to 3 d earlier than 'Catrachita', with physiological maturity from 2 to $4 \mathrm{~d}$ earlier than 'Catrachita'.

No line was identified that combined the earliness of 'Cuarentena' and 'Cuarenteño' with the greater yield potential of L227-1 and 'Catrachita'. However, some lines in all of the populations yielded as well as L227-1 or 'Catrachita' while maturing in fewer days. Most of these lines had significantly greater rates of seed mass accumulation than the early cultivars 'Cuarentena' and 'Cuarenteño'.

A few lines yielded more than 'Catrachita' or L227-1 by combining long reproductive periods with greater rates of seed mass accumulation. However, the frequency of these lines in all populations was low and the identification of higher yielding lines with this combination of traits will require evaluation of large populations. Although this research demonstrates that the length of the filling period and the rate of seed fill affect yield potential and days to maturity of beans, it would be too costly to select directly for these traits in an applied breeding program. Determination of seed yield and days to maturity should identify lines with the most desirable combination of reproductive period and rate of seed yield accumulation. These results suggest that early-maturity whiteseeded and small red bean lines with higher yield potential can be selected. In addition, the yield of later maturing bean lines can be increased by selecting lines that combine a long reproductive period with a fast rate of seed mass accumulation.

Because the small red- and white-seeded parents were of similar seed size, differences in progeny yields primarily reflected differences in seed number per plant. Egli (1994) noted that much of the variation in yield of soybean was associated with variation in seed number and that yield primarily is source limited.

These results demonstrate that lines can be selected from these populations that maintain yield potential but that are from 4 to $7 \mathrm{~d}$ earlier maturing than L227-1 or 'Catrachita'. This earlier maturity may be critical when drought or cisease threaten the crop toward the end of the growing season. Because the populations in this study were evaluated under irrigated conditions, the earlier-maturing lines may have greater yield potential than 'Cuarentena' or 'Cuarenteño' in environments where rainfall is not limiting. Cultivars were identified in Mexico that can adapt to different rainfall patterns by modifying phenological development (Acosta-Gallegos and White, 1995).

'Cuarentena' and 'Cuarenteño' are among the earliest maturing cultivars in their seed class, and no lines were selected that matured as early as either cultivar and yielded as well as L227-1 or 'Catrachita'. Hartwig (1970) found that soybeans grown under short-day tropical conditions needed at least $45 \mathrm{~d}$ of vegetative growth to produce acceptable yields. McNeal et al. (1972) noted that wheat (Triticum aestivium L.) plants require a minimum amount of vegetative growth to act effectively as a grain producing entity. In soybeans, Egli (1994) found little yield advantage associated with larger plants once a minimum plant size is reached.

\section{Literature Cited}

Acosta-Gallegos, J.A. and J.W. White. 1995. Phenological plasticity as an adaptation by common bean to rainfed environments. Crop Sci. 35:199_ 204.

Adams, M.W. 1967. Basis of yield component compensation in crop plants with special reference to field bean (Phaseolus vulgaris L.). Crop Sci. 7:505-510.

Badillo-Feliciano, J., I. Reyes-Soto, and J.S. Beaver. 1985. A comparison of yields of common bean at physiological and harvest maturity. J. Agr. Univ. Puerto Rico 69:19-24

Beaver, J.S. and J.D. Kelly. 1994. Comparison of selection methods for dry bean populations derived from crosses between gene pools. Crop Sci. 34:34-37.

Beaver, J.S. and J.C. Rosas. 1992. Selection of beans with greater reproductive periods. Annu. Rpt. Bean Improv. Coop. 35:13-14.

Cerna, J. and J.S. Beaver. 1989. A visual indicator of the physiological maturity stage of indeterminate common beans. J. Agr. Univ. of Puerto Rico 73:361-366. 
Centro Internacional de Agricultura Tropical. 1987. Standard system for the evaluation of bean germplasm. A. van Schoonhoven and M.A. Pastor Corrales (compilers). CIAT, Cali, Colombia.

Egli, D.B. 1994. Seed growth and development, p. 127-148. In: K.J. Boote (ed.). Physiology and determination of crop yield. Amer. Soc. Agron., Madison, Wis.

Hartwig, E.E. 1970. Growth and reproductive characteristics of soybeans grown under short day conditions. Trop. Sci. 12:809-812.

Izquierdo, J.A. and G.L. Hosfield. 1983. The relationship of seed filling to yield among common beans with differing architectural forms. J. Amer. Soc. Hort. Sci. 108:106-111.

Janssen, W. 1989. A socio-economic perspective on earliness in beans, p. 135-155. In: S. Beebe (ed.). Current topics in breeding of common bean.
Working Document no. 47. CIAT, Cali, Colombia.

McNeal, F.H., M.A. Berg, V.R. Stuart, and D.E. Baldridge. 1972. Agronomic response of three height classes of spring wheat (Triticum aestivium L.) compared at different yield levels. Agron. J. 61:290-293. Pfeiffer, T.W. and D.B. Egli. 1988. Heritability of seed filling period estimates in soybean. Crop Sci. 28:921-924.

Smith, J.R. and R.L. Nelson. 1986. Relationship between seed filling period and yield among soybean breeding lines. Crop Sci. 26:469-472.

Wallace, D.H., R.W. Zobel, and K.S. Yourstone. 1993. A whole-system reconsideration of paradigms about photoperiod and temperature control of crop yield. Theor. Appl. Genet. 86:17-26.

White, J.W. and S.P. Singh. 1991. Sources and inheritance of earliness in tropically adapted indeterminate common bean. Euphytica 55:15-19. 